Научная статья

УДК 304.4

DOI 10.18101/2306-630X-2020-1-16-21

\title{
ЗАПАДНИЧЕСТВО И СЛАВЯНОФИЛЬСТВО: ДВЕСТИ ЛЕТ СПУСТЯ
}

\author{
(C) Багаева Ксения Анатольевна
}

кандидат философских наук, доцент кафедры философии

ksyusha.81@mail.ru

\section{(C) Жапова Наталья Амогалановна}

кандидат философских наук, ст. преподаватель кафедры философии tumann4@rambler.ru

Бурятский государственный университ имени Доржи Банзарова Россия, 670000, г. Улан-Удэ, ул. Смолина, 24а

\begin{abstract}
Аннотация. Статья посвящена проблеме противостояния взглядов славянофилов и западников, а именно расхождению в вопросе о будущем пути развития России. Авторы обращают внимание идеи славянофилов и западников в контексте современного взгляда, обращаясь к тем концепциям и течениям, которые органично продолжают их идеи. В статье указывается, что сейчас это идейное противостояние актуально, поскольку российское общество все еще находится в поисках пути социокультурного развития. Также отмечается, что, несмотря на преемственность взглядов современных продолжателей славянофилов и западников, прослеживается новый модернизированный фокус рассмотрения проблем исходя из требований XXI в. Авторы делают вывод о противоречивости идей как славянофилов, так и западников прошлого и современного времени. Однако существует необходимость обратить внимание на их взгляды.

Ключевые слова: русская философия; западничество; славянофильство; путь России; Европа; российское общество; русское национальное самосознание.
\end{abstract}

\section{Для цитирования}

Багаева К. А., Жапова Н. А. Западничество и славянофильство: двести лет спустя // Евразийство и мир. 2020. № 1. С. 16-21.

В современном российском обществе по-новому происходит осмысление социокультурных процессов. В этом аспекте представляют интерес работы славянофилов и западников XIX в., тем более что существует современное прочтение их взглядов. Идеи славянофилов и западников тогда и в настоящее время представлены в противопоставлении друг другу.

Западники прошлого выступали за сближение России и Европы, следование европейскому социокультурному пути, тогда как славянофилы, наоборот, считали, что у России свой особый путь развития. Западничество и славянофильство как философские направления своими корнями уходят в реформы Петра I, когда произошло заимствование немецких просветительских идей и культурных особен- 
ностей. Процесс этот был неоднозначный, так как не все принимали идеи немецкой просветительской философии.

В российском обществе противостояние между славянофилами и западниками начало проявляться с началом перестройки, поэтому период с 90-х гг. прошлого века по настоящее время - это время западничества. Однако сейчас усиливается тенденция обращения к идеям славянофилов, это связывается с ростом интереса к национальному аспекту, народным традициям, повышению роли православия в обществе. Отметим также в качестве факторов обращения к этой теме особенность русского национального самосознания, противоречивость социокультурного развития, отсутствие устойчивого пути, которое было утеряно после коммунистической идеологии. Все это является причинами для научного интереса к проблемам, поднимаемым спором между направлениями, а главное, актуальности этих проблем, тем более что отмечается противоречивый характер современных исследований.

Современное западничество представлено либерально-демократическим течением, берущим за основу геополитику и международные теории экономики. В контексте этого западники занимаются исследованием отношений Запада и России, проблемами модернизации и ее применения на российской почве. К этому течению принадлежит В. Л. Иноземцев, активно полемизирующий со славянофилами. Ученый высказывается против идеи о России как занимающей особое место в мире. Ученый обращается к концепту Ф. М. Достоевского о «Русском мире», суть которого заключается в представлении в необходимости следования русским традиционным ценностям. Концепт опирался на мессианскую роль России, которая является объединяющим фундаментом для россиян, находящихся за границей. Первую часть концепта составляет идея о том, что люди, самостоятельно покинувшие страну, устраиваются достойно, становятся профессионалами своего дела, тем самым показывая, что обладают профессиональной идентичностью, а не национальной. Эти люди не расширяют границы России и ее влияние вне страны, они формируют русский мир. Вторую часть концепта представляет мысль о том, что люди, оказавшиеся за пределами страны в результате распада союза, активно демонстрируют свою принадлежность к русскому миру. И это две совершенно разные части.

В. Л. Иноземцев предлагает партнерство «двух Россий» собственно России и самостоятельного, уверенного в себе мира русских профессионалов за пределами РФ - это самое эффективное партнерство ради модернизации, которое только можно представить [1, с.154]. Для этого необходимо приблизиться к Европе, вступить на путь модернизации. Обращаясь к концепту «Русский мир», исследователь видит его несостоятельность, потому как он возвращает ко времени, когда отсутствовали национальные государства. А в условиях, когда российское общество стремится к гражданскому, такой концепт не выдерживает критики, по его мнению. Кроме того, он считает, что многие политики используют его в целях обоснования особой роли России в мире. Но это опасно для России, потому как в этом случае концепт становится лишь инструментом в политических целях.

В аспекте западничества, нам представляется возможным рассмотреть А. А. Ахиезера, выдвинувшего оригинальную идею о социокультурной истории России. История человечества, как считает А. С. Ахиезер, это смена цивилизаций 
как формы социокультурной общности. Ученый следующим образом обосновывает необходимость цивилизационного подхода: «Цивилизационный подход нацелен на выявление специфики каждой цивилизации, но и анализ их единства в масштабе мировой истории » [2, c. 83]. Поэтому изучение цивилизаций - это исследование способности к развитию, к изменению своей роли в мировой культуре. Таким образом, главная задача российского общества - «найти путь усиления массовой способности эффективно решать жизненно важные проблемы, обеспечивать свою выживаемость, жизнеспособность в усложняющемся мире» [2, с. 83]. Жизнеспособность основывается на основании изучения социальной реальности, А. С. Ахиезер, задаваясь вопросом: «Почему, однако, возникает сама проблема цивилизационной альтернативы как собственной проблемы субъекта?», и отвечает на него так, что знать историю недостаточно [2, с. 87]. Социокультурная теория исследует смыслы, механизмы развития усложняющейся реальности. Обращаясь к России, исследователь находит в ее истории множество национальных катастроф, поэтому она не может решить проблемы все усложняющейся реальности, идеи дезорганизации общества, исторического процесса.

Поскольку Россия - это, согласно концепции А. С. Ахиезера, традиционное общество и двигается по инерции, но путь этот труден, так как может существовать только в неизменном мире, а мир на самом деле изменчив. Россия должна найти гармонию между происходящими в мире изменениями и своим традиционным состоянием, то есть адаптироваться. «Поиск наилучшего соотношения между воспроизводством старого и движением к новому в России сильнейшим образом затруднен существующим расколом по поводу основополагающих принципов формирования социальных программ» [3, с. 88]. Есть путь, направленный на традиционализм, другой - на модернизм. Модель цивилизационная возникает в условиях выбора, когда нужно ориентироваться на новые пути, либо продолжать следовать традиционализму, причем учитывая мировой опыт. Кроме того, цивилизационная альтернатива может возникнуть в том случае, если люди осознают свой выбор. Россия, считает он, должна стремиться к изменениям, существующий традиционализм не сможет остановить либеральные реформы, «историческая инерция, несущая в себе программы выживаемости, может стать основой для воспроизводственной деятельности субъекта лишь при условии, если запечатленный в культуре опыт исторически накопленных решений осваивается субъектом» [3, с. 95]. Без субъекта понимание реальности невозможно, поэтому нужно осмысливать все те изменения, что уже произошли, тем самым становясь на ступень выше, обеспечивая себе выживаемость.

Таким образом, отметим все ту же продолжающуюся тенденцию современного западничества веры в прогресс как совершенствование, движение к равенству наций, классов.

Обратимся к современным славянофилам, которые активно сигнализируют о размывании границ национальных и этнических культур, что может привести к потере самобытности русской культуры. Поэтому в наше время, указывают славянофилы, кризис гораздо сложнее, чем ранее. «Без старины нет замыкания. Нет мудрости целого. И ты на прямой линии. То есть тебя несет из одной бесконечности в другую. Неизвестно куда. И неизвестно откуда. В никуда. Старина нам дает возможность 
быть самим собой. Иметь свой голос» [4, с. 54]. Тем самым славянофилы противопоставляют Европу и Россию, выделяя превосходство традиционных ценностей и национальной самобытности, обращение к старине и особый путь России - все те же идеи славянофилов в контексте современности.

Так, С. С. Хоружий, анализируя наследие славянофилов, отмечает, что славянофилы творчески и по-новому подходили к решению проблем. Он пишет: «Традиция, рисуемая славянофилами, и уж тем паче ее восстановление могли быть утопией; но их идейные разработки были реальным творчеством. Логикою вещей, именно традиционалисты-славянофилы, а не прогрессисты-западники оказывались призваны к новой постановке философских, религиозных, историософских проблем, к созданию моделей и парадигм российского исторического духовного процесса. В этом коренится их особая роль в развитии русского самосознания, прочно признанная сегодня и русской, и западной наукой» [6]. Как считает исследователь, именно славянофилы поставили в центр размышлений проблему русского самосознания, с чем трудно не согласиться.

У другого последователя славянофильской традиции А. С. Панарина находим синтез идей «старых» и новых славянофилов, который приводит его к созданию учения о будущем России. Его концепция обосновывает сакрализацию государства и соборную идентичность, поэтому логично его негативное отношение к либерализму и западничеству. Для него предпочтительнее социализм, чем либерализм, соответственно в России возможен социализм в христианской интерпретации, которых объединяет идея помощи и сочувствия слабым. Главная роль здесь в спасении отдается православию.

В некотором смысле А. С. Панарин выступает как неоевразиец, когда пишет о русификации Евразии, что отличается от проекта А. Г. Дугина, предлагающего неверно отделить Россию от Европы. Поэтому у Панарина Россия превратит Евразию в особый, отличный от Европы мир. Ведущее место автор в концепции отдает православию, которое будет вести за собой евразийскую идею. В этом проекте также будет реализована идея социальной справедливости.

Таким образом, видим в его концепции продолжение идей В. С. Соловьева, Н. А. Бердяева, Ф. М. Достоевского. В своей альтернативной концепции русского миропорядка он предлагает провести глобализацию на христианском основании, что будет более мягким вариантом современной глобализации и позволит сохранить ее нравственную оболочку.

Обобщая вышесказанное, отметим, преемственность и наследственность идей современных славянофилов и западников. Так, славянофилы видели идеал российского общества, который может быть реализован через православие, что их одновременно и ограничивает, и возвышает над другими. Древняя Русь может показать пример традиционализма и соответствует в большей степени русскому духу, что стало отправной точкой для размышлений славянофилов. Их философские построения отражают дух эпохи, как ушедшей, так и современной, что отразилось в поиске дальнейшего пути России. Исследуемые ими вопросы отражают смысложизненные проблемы российской действительности, только сегодня эти вопросы освещаются через призму современности. 
Западничество, отдавая предпочтение ценностям западного общества - равенству, свободе и правам личности, либерализму, отстаивает и сейчас тезис об исторической и культурной принадлежности России к западной цивилизации, но дополняет все это идеями о модернизации и секуляризации.

«Славянофилы, как и западники, не разрешили вопросов русского общества. Однако они осветили многие стороны славянского народного характера, быта и истории; они определили русское национальное самосознание как религиозное по духу и цели, а также поставили перед нашим самосознанием основную тему Востока и Запада» [7, с. 101]. Также и сейчас отмечаются попытки нахождения пути России от консервативно-радикальных в виде возвращения к традиционализму, полному отделению России от европейского общества, до либерально-демократических, призывающих к модернизации по западному пути.

В вековом споре прослеживается выработка новых ориентиров, нравственного идеала, нужных в любое время обществу. Славянофилов и западников объединяет одна мысль о России, но в рамках своего направления, что первые, что вторые показывают свою индивидуальность, неповторимость и самостоятельность мышления. Поэтому их идеи требуют дальнейшего рассмотрения, нового подхода, ведь время формирует новые условия для существования, ставит новые цели и задачи. Разные и противоречивые взгляды на путь России только подчеркивают ее особенность.

Литература

1. Иноземцев В. Л. Русский мир против Русского мира // Социологические исследования. 2015. № 5. С. 154.

2. Ахиезер А. С. Цивилизационный выбор России и проблема выживаемости общества // Россия и современный мир. 2002. № 2. С. 83.

3. Ахиезер А.С. Архаизация в российском обществе как методологическая проблема // Общественные науки и современность. М., 2001. № 2. С. 88.

4. Гиренок Ф. И. Патология русского ума. Картография дословности. М., 1998. С. 54.

5. Walicki. A. W kregu konserwatiwnej utopii: Struktura i przemiany rosyiskiego slowianofilstwa. Warszawa, 1964. S. 367.

6. Хоружий С. С. Современные проблемы православного миросозерцания. М., 2002. C. 19 .

7. Жигунова Г.В. Общественный идеал в России в духовном наследии славянофилов. М.: Директ-Медиа, 2014. С. 101.

\section{WESTERNISM AND SLAVOPHILISM: TWO HUNDRED YEARS LATER}

Kseniya A. Bagaeva

Cand. Sci. (Philos.), A/Prof. of Philosophy Department,

Dorzhi Banzarov Buryat State University

24a Smolina St., Ulan-Ude 670000, Russia

ksyusha.81@mail.ru 
Natalya A. Zhapova

Cand. Sci. (Philos.), Senior Lecturer of Philosophy Department, Dorzhi Banzarov Buryat State University 24a Smolina St., Ulan-Ude 670000, Russia tumann4@rambler.ru

Abstract. The article is devoted to the problem of opposing the views of Slavophiles and Westerners, namely, the divergence in the issues of the future path of Russia's development. We draw attention to the ideas of Slavophiles and Westerners in the context of the modern view, referring to those concepts and trends that naturally complement them. The article emphasizes the relevance of this ideological confrontation, since the Russian society today is still in search for a way of socio-cultural development. It is also noted that, despite the continuity of views of modern successors of Slavophiles and Westerners, we can trace a new modernized focus of problems consideration, based on the requirements of the $21 \mathrm{st}$ century. We have concluded that the ideas of both Slavophiles and Westerners of the past and modern times are contradictory; nevertheless there is a need to pay attention to their views.

Keywords: Russian philosophy; Westernism; Slavophilism; the way of Russia; Europe; Russian society; Russian national consciousness.

Статья поступила в редакцию 22.05.20; одобрена после редактирования 11.06.20; принята к публикации 30.10.20. 